\title{
Achieving Millennium Development Goals and India Vision 2020: Evidences from the Slums of Varanasi City
}

\author{
Darshan Kumar Jha ${ }^{\dagger}$ and Dr. V.K. Tripathi*
}

\section{Abstract}

The objective of this paper is to examine the achievements of Millennium Development Goals (MDGs) and India Vision 2020 in the context of the slums of Varanasi city. India has been facing the problem of growing urban poverty due to rapid urbanisation. According to the Census of India 2011, about 65 million people live in urban slums, which are overcrowded, polluted, unhygienic, and deprived of basic services. This paper compares the goals and targets of UN MDGs and India Vision 2020 with the status of the slum dwellers of Varanasi city. The study is based on primary data, which includes survey of 150 households of five different slums of Varanasi city. The study reveals that more than $70 \%$ people are illiterate, less than $35 \%$ of population access government health facilities, only $36 \%$ household use tap water, etc. This comparison portrays a pathetic picture of slums and the inabilities to achieve both MDGs and national goals.

Key words:MDGs, India Vision 2020, Slums, Poverty, Quality of life, Varanasi City, India

\footnotetext{
†Junior Research Fellow, Dept. of Geography, Banaras Hindu University, Varanasi-221005, Email:darshanjha@gmail.com

${ }^{*}$ Associate Professor, Dept. of Geography, Banaras Hindu University,Varanasi-221005, Email: vktbhu2004@gmail.com (C)2015 Jha and Tripathi. This is an Open Access article distributed under the terms of the Creative Commons Attribution License (http://creativecommons.org/licenses/by/2.0), which permits unrestricted use, distribution, and reproduction in any medium, provided the original work is properly cited.
} 


\section{Introduction}

Central to planning is about increasing the quality of life (QOL). The goals and targets for various QOL indicators are set at global and national level. In September 2000, world leaders met at the United Nations Millennium Summit to establish a series of goals for humanity in the 21st century. Central idea of Millennium Declaration was the right to dignity, freedom, equality and a basic standard of living (that incorporates free from hunger, violence but increased tolerance and solidarity (Kabeer, 2010). The summit resulted in the ratification of the Millennium Declaration and the Millennium Development Goals (MDGs), a set of 8 global goals and 21 targets to be measured through 60 indicators. The MDGs focus on the three major areas of improving infrastructure, increasing social, economic and political rights with the majority of focus going towards increasing basic standards of living (MDGUNDP, 2006). The goals are focused on reducing poverty, improving the quality of people's lives, ensuring environmental sustainability and building partnerships to make a positive use of globalisation. The overarching goal is to halve absolute poverty in the world by the end of 2015. More than a decade later, the world has witnessed considerable progress and successes in achieving these goals. Yet, this progress has bypassed large numbers of the world's poor. India Vision 2020 document is a projection of India in 2020 by the Planning Commission of India [now replaced by National Institution for Transforming India (NITI Aayog)]. It examines various issues related to poverty and inclusive development such as education, employment and population growth, vulnerable sections of the population, environmental quality and governance. It states, "by 2020, the people of India will be more numerous, better educated, healthier and more prosperous than at any time in our long history" (India Vision, 2020:3). India has been facing the problem of growing urban poverty due to rapid urbanisation. According to the Census of India 2011, about 65 million people live in urban slums, which increased from approximately 52 million in 2001, recording
25.1\% decadal growth rate, but with slight decrease in overall slum population percentage in reported towns from $23.5 \%$ in 2001 to $22.4 \%$ in 2011. Seemingly, 2613 towns reported slums in 2011. These slums are typically overcrowded, polluted and dangerous, and lack basic services such as clean water and sanitation. Varanasi, one of the oldest living heritage cities of the world, faces the challenges of rapid urbanisation and growing slums that portray a pathetic picture of the lives in slums.

Social problems, disparities, well-being and QOL are the new domains of geographic study in this post-modern era. The QOL studies are becoming more relevant for inclusive development of society and country. The rapid growth of slums and informal settlements has largely contributed to the social, economic and environmental problems in urban areas. Today, QOL seems essential to express and explain the socio-economic pattern and well-being of a society and its different strata. After the work of Smith (1977), geographers took interest in the study of social well-being. Since the late 1980s, poverty, and more specifically urban poverty, has experienced a significant resurgence of attention in most regions of the world. Currently, urban poverty has attracted researchers from different disciplines. Nath (2011) examined various programs and policies related to the MDGs and observed slow progress towards achieving these goals. She also observed that the utilisation of services offered by different programs is rather low. Ishtiyaq \& Kumar (2011) studied informal settlements and distribution of slums in the National Capital Territory (NCT) of Delhi and found lack of basic amenities in these settlements. Bandyopadhyay and Agrawal(2013) reviewed condition of slums in India from the past to the present and observed that urban areas are facing lots of problems and unable to access affordable land, employment, basic amenities and social services to the poor. Cohen (2013) argues that Millennium Development Goals (MDGs) have ignored the urbanisation process and rate of urban population growth. He also examines the other limitations of MDGs and suggests some 
new targets for post 2015 period. In this postmodern globalised era where economic growth and disparities co-exist, the study of human well-being and QOL are more significant. Against these backgrounds, this paper is an attempt to compare the QOL of slum dwellers with the targets of UN MDG and India Vision 2020 and suggest some measures for inclusive development and planning to improve the QOL in slums.

\section{Objectives}

The study was undertaken with the following objectives:

- To present an overview of QOL in slums in Varanasi city.

- To compare the QOL in slums of Varanasi city with the MDGs and India Vision 2020.

\section{Data and Methodology}

The study is based on primary data collected through an interview schedule in 150 households of selected slums (Rajghat, Onkareshwar, Sigra, Durgakund and Nagwa) in the city of Varanasi. The paper highlights the low quality of level of slum dwellers of Varanasi city with the help of various indicators of QOL. Altogether, 10 variables(X1 to $\mathrm{X} 10)$ have been carefully chosen to determine the existing QOL (please refer to Table 3). Finally, the paper compares the status of the slum dwellers with that of the goals and targets of the MDGs and India Vision 2020.

\section{Study Area}

Varanasi (also known as Kashi or Banaras is located in between $82^{\circ} 56^{\prime} \mathrm{E}-83^{\circ} 03^{\prime} \mathrm{E}$ and $\left.25^{\circ} 14^{\prime} \mathrm{N}-25^{\circ} 23^{\prime} \mathrm{N}\right)$, a cultural and spiritual capital of India bearing a continuous history dating back to 3,000 to 5,000 years and situated on the left crescent-shaped bank of the river Ganga, a part of 'Varanasi Urban Agglomeration' (VUA). Due to increasing population growth and rapid development of Varanasi, it transformed into a million-city in 1991. Rapid urbanisation has increased manifold urban problems in Varanasi city such as inadequate housing, proliferation of slums, inadequate water supply and sanitation, environmental pollution, poor social infrastructure, etc.

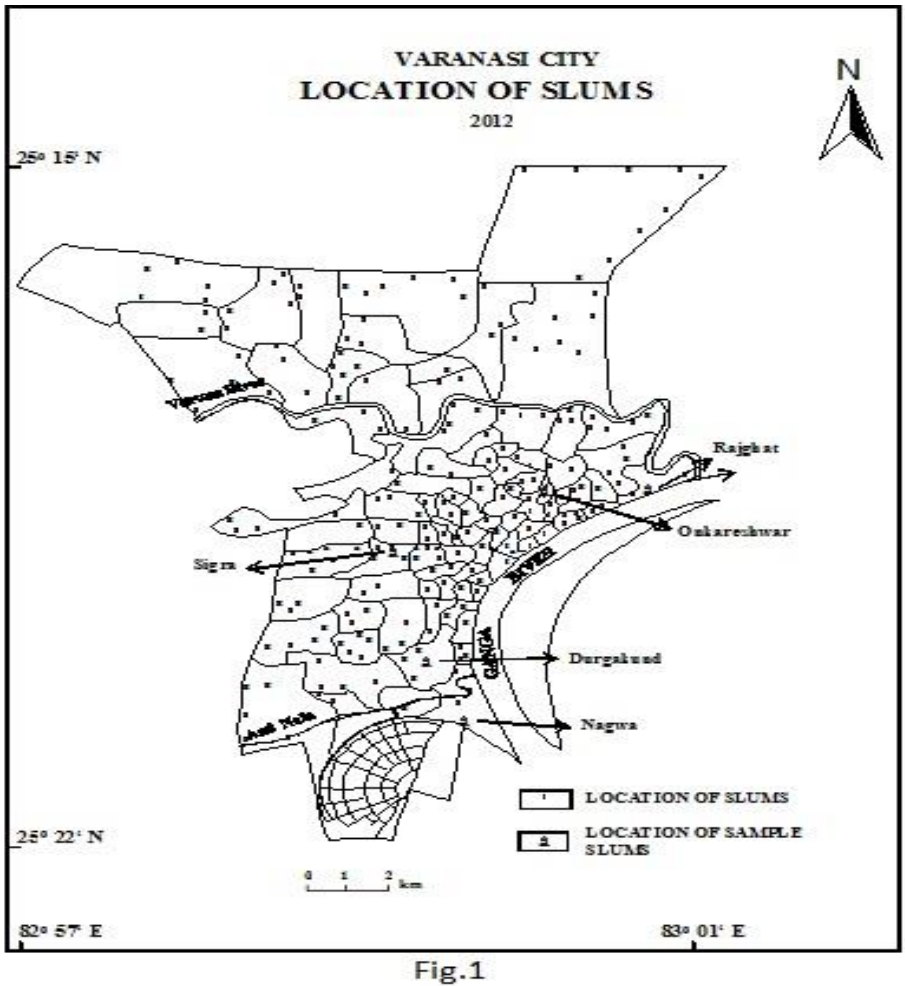

Figure 1 


\section{Slums in Varanasi City}

Slums in Varanasi city has been increasing continuously from 1941 to 2011. With the increase in population of the city, housing needs of the city also grew, which the formal housing market failed to meet. Migrating population, which could not avail the facilities of formal housing market, satisfied their needs by occupying vacant lands and this has resulted in the growth of slums. Another factor, which contributes to the formation of slums, is proximity to work place and low level of income and un-affordability of pucca or permanent houses (City Development Plan, 2006). People living in the slums of Varanasi city are poor working as labour, rickshaw-pullers and thela (cart) keepers (Tripathi, 2010). Out of 106 wards in the city, 61 wards have slum areas. The population of urban poor and slum dwellers in Varanasi accounts for about 37.69\% of the city's population. Table 1 shows population projection on decadal growth rate, slum population and population below poverty line (BPL).

Slum locations are spread all over the city but major concentrations are in the old city areas, that is, near the Ghats, industrial units and the Rajghat area due to proximity to work place. Employment due to tourism and availability of open land has led to indiscriminate squatting (Tripathi, 2011). Varanasi has 227 slums spread all over the city, either on government or private lands. About $50 \%$ of slums are located in central city, $13 \%$ in old city while $37 \%$ in peripheral areas. The average density in slum areas is approximately 330 persons per hectare in the city area. Table 2 gives an overview of slums in Varanasi city.

\section{Table 1: Population Projection on Decadal Growth Rate}

\begin{tabular}{llll} 
Year & Total Population & Slum Population & BPL Population \\
\hline 2001 & $12,02,443$ & $4,53,222$ & 96,344 \\
\hline 2006 & $13,70,785$ & $5,16,668$ & $1,09,787$ \\
\hline 2011 & $15,35,279$ & $5,78,646$ & $1,22,962$ \\
\hline 2021 & $19,65,157$ & $7,40,667$ & $1,57,391$ \\
\hline 2031 & 2574,356 & $9,70,274$ & $2,06,183$
\end{tabular}

Source: District Urban Development Authority (DUDA), Varanasi, 2006

\begin{tabular}{lllllll}
\hline \multicolumn{7}{c}{ Table 2: Slums in Varanasi: An Overview } \\
& $\begin{array}{l}\text { No. of } \\
\text { House } \\
\text { Hold }(\mathrm{HH})\end{array}$ & Population & Area(Ha) & $\begin{array}{l}\text { Density } \\
\text { (person/Ha) }\end{array}$ & HH size & $\begin{array}{l}\text { Average } \\
\text { Income } \\
\text { (₹/Day) }\end{array}$ \\
\hline Varanasi City & 151654 & 1202433 & 7979 & 150 & 7.3 & NA \\
\hline Slums & 57055 & 453222 & 1372.6 & 330 & 8 & $100-150$ \\
\hline Percentage & 37.6 & 37 & 17 & - & - & - \\
\hline
\end{tabular}

Source: District Urban Development Authority (DUDA), Varanasi, 2006

\section{Profile of Sample Slums}

For this research, field survey was conducted in 2012 in 5 wards, namely, Nagwa, Durgakund, Sigra, Onkareshwar and Rajghat wards - all located in different parts of Varanasi city (Fig. 1). In these 5 wards, altogether 150 households were selected having a total population of 678 persons. The Nagwa ward is located in the southern part of the Varanasi city adjacent to the western side of BHU and Ganga River. In this ward, 25 households were surveyed. Sigra ward is situated in the middle part of the city. In this ward, the slum is located on the front of the Sampurnanand Sport Stadium, where 25 households were surveyed. Due to location on the main road the position of dwellings are better than other slums. The slum of 
Durgakund ward is situated on the western side of Lanka-Ravindrapuri road. Here, the dwellers belong to a specific community of sweeper. The living standard and economic status is comparatively better than the dwellers of Nagwa ward. 25 households were surveyed in this ward. The slum area of Onkareshwaris known as Hasanpur. This is situated on the western skirt of Machhodari Park surrounding the Onkareshwar Shiva temple. In this ward, 50 households were surveyed. Rajghat slum (Kazzakpura) is situated in the eastern part of Varanasi on the east of Varanasi-Mughalsarai main road near Ganga River where 25 households were surveyed.

\section{Indicators of quality of life}

In this research, altogether 10 variables have been carefully chosen to determine the existing $\mathrm{QOL}$ in the slums of Varanasi (for details, please refer to Table 3).

Source of lighting (X1): Electricity is considered as a parameter of measurement of development and QOL. The survey revealed that $70 \%$ of sample households in slums use electricity, while $30 \%$ household use kerosene as a source of lighting. However, it is notable that majority of household had no legal electricity connection.

Fuel used for cooking (X2.): The survey revealed that $36 \%$ households use LPG for cooking. However, many of them have not received LPG connection; they use the small cylinders of $2 \mathrm{~kg}$ and $4 \mathrm{~kg}$. The $32 \%$ slum dwellers use illegal electric connection for illuminating their heaters. Kerosene, coal and cow-dug-cakes are other fuels used for cooking.

Source of drinking water (X3): Safe and pure drinking water is the basic need for life. According to world resources (1998-99), more than 1.4 billion people in developing countries lack access to safe drinking water, which is one of the essentials for good health. The sample survey reveals that $64 \%$ residents of slum areas use water from hand pump, while $36 \%$ use water from municipal tap for drinking. The quality of water from hand pump is not of good quality.
Housing condition (X4): One billion people of the world live in inadequate housing, mostly in slums and squatter settlements. The situation is worst in urban areas of developing countries, where one quarter of housing units are of temporary structure.A deplorable scenario exists in the sample region, where all the sample slums are dominated by kachha (temporary) and semi-pucca (semi-permanent) housing structure. Out of 150 houses, 128 houses had only one room. Durgakund slum had more pucca or permanent houses (30\% of households) than any other slum.

Sewage disposal facility (X5): Sanitation is not only important for healthy living but also ensures a non-polluted environment. The majority of sample households had poor sewage disposal facility. The condition of Onkareshwar, Sigra and Durgakund is worst where more than half of the sample households had poor sewage facilities.

Solid waste disposal site (X6): The risk to human health are compounded in these slums, where garbage collection is non-existent in most cases and drainage tends to be poor, promoting the growth of insects and other diseases vectors (Sundari, 2003). There is no adequate arrangement for dumping of domestic wastes. Only one-third households used the place fixed by municipality for dumping of domestic wastes.

Medical facilities (X7): Medical facility is a significant parameter of measurement of QOL. The $48 \%$ slum dwellers used private clinic and $35 \%$ government hospitals, while $17 \%$ used traditional medical practitioners. The condition of Onkareshwar is better than other slums.

Literacy (X8): Due to widespread poverty in the slum areas, illiteracy prevails and even it can be said that poverty exists because illiteracy exists (Tripathi, 2010). The literacy is the most significant indicator of socio-economic condition and QOL. Though literacy rate is very poor in the slums of Varanasi city, comparatively Sigra and Nagwa wards are better in literacy rate than other wards. 
Female literacy (X9): Female literacy is not only an indicator of education but it also refers to the status of women in society. The sample area had very poor female literacy, which indicates massive gender inequality in these slums of Varanasi.

Ration card type (X10): Ration card is a parameter of classifying poverty-stricken people in India. Red ration cardholders are people below poverty line while yellow cardholders are people above poverty line. 25\% households in the slums do not have any kind of ration card. The reason for not holding any card is unawareness and lengthy documental procedures.

\section{Table 3: Selected Variables for Quality Of Life of Slum Dwellers of Varanasi city}

\begin{tabular}{|c|c|c|c|c|c|c|c|c|}
\hline \multirow{3}{*}{ Variables } & \multirow{3}{*}{ Parameters } & \multirow{3}{*}{ Indicators } & Rajghat & Onkareshwar & Sigra & Durgakund & \multirow{3}{*}{$\begin{array}{c}\text { Nagwa } \\
\% \text { of } \\
\mathrm{HH}\end{array}$} & \multirow{3}{*}{$\begin{array}{c}\text { Total } \\
\% \text { of } \\
\mathrm{HH}\end{array}$} \\
\hline & & & $\%$ of & & $\%$ of & & & \\
\hline & & & $\mathrm{HH}$ & $\%$ of $\mathrm{HH}$ & HH & $\%$ of $\mathrm{HH}$ & & \\
\hline \multirow{2}{*}{$\mathrm{X} 1$} & \multirow{2}{*}{$\begin{array}{c}\text { Source of } \\
\text { lighting }\end{array}$} & Electricity & 70 & 64 & 68 & 72 & 76 & 63.6 \\
\hline & & Kerosene & 30 & 36 & 32 & 28 & 24 & 26.4 \\
\hline \multirow{6}{*}{$\mathrm{X} 2$} & \multirow{6}{*}{$\begin{array}{l}\text { Fuel used } \\
\text { for cooking }\end{array}$} & LPG & 26 & 40 & 48 & 40 & 36 & 36 \\
\hline & & Electricity & 24 & 16 & 12 & 20 & 32 & 21.33 \\
\hline & & Kerosene & 18 & 16 & 20 & 16 & 12 & 16.66 \\
\hline & & Coal & 12 & 16 & 12 & 8 & 8 & 11.33 \\
\hline & & Cow-dug- & & & & & & \\
\hline & & cakes & 20 & 12 & 8 & 16 & 12 & 14.66 \\
\hline \multirow[t]{2}{*}{$\mathrm{X} 3$} & \multirow{2}{*}{$\begin{array}{c}\text { Source of } \\
\text { drinking } \\
\text { water }\end{array}$} & $\begin{array}{c}\text { Municipal } \\
\text { tap }\end{array}$ & 30 & 44 & 48 & 36 & 28 & 36 \\
\hline & & Hand pump & 70 & 56 & 52 & 64 & 72 & 64 \\
\hline \multirow{3}{*}{$X 4$} & \multirow{3}{*}{$\begin{array}{l}\text { Housing } \\
\text { condition }\end{array}$} & Pucca & 10 & 12 & 20 & 30 & 8 & 15 \\
\hline & & Semi pucca & 60 & 52 & 62 & 64 & 70 & 61.33 \\
\hline & & Kaccha & 30 & 36 & 18 & 6 & 22 & 23.66 \\
\hline \multirow[b]{2}{*}{$\times 5$} & \multirow{2}{*}{$\begin{array}{c}\text { Sewage } \\
\text { disposal } \\
\text { facility }\end{array}$} & Average & 56 & 36 & 40 & 35 & 55 & 46.33 \\
\hline & & Poor & 44 & 64 & 60 & 65 & 45 & 53.66 \\
\hline \multirow{4}{*}{$x 6$} & \multirow{4}{*}{$\begin{array}{l}\text { Place of } \\
\text { waste } \\
\text { dumping }\end{array}$} & Area Fixed by & & & & & & \\
\hline & & Municipality & 28 & 28 & 24 & 24 & 12 & 24 \\
\hline & & On roads & 60 & 56 & 64 & 68 & 48 & 56 \\
\hline & & $\begin{array}{c}\text { Near water } \\
\text { bodies }\end{array}$ & 12 & 16 & 12 & 8 & 60 & 20 \\
\hline \multirow{4}{*}{$x 7$} & \multirow{4}{*}{$\begin{array}{l}\text { Medical } \\
\text { facilities }\end{array}$} & $\begin{array}{c}\text { Govt. } \\
\text { Hospital }\end{array}$ & 40 & 40 & 36 & 16 & 36 & 34.66 \\
\hline & & Private clinic & 50 & 44 & 48 & 56 & 40 & 48 \\
\hline & & Traditional & & & & & & \\
\hline & & Practitioner & 10 & 16 & 16 & 28 & 24 & 17.33 \\
\hline \multirow{2}{*}{$\mathrm{x} 8$} & \multirow{2}{*}{$\begin{array}{l}\text { Literacy } \\
\text { (\% pop.) }\end{array}$} & Literate & 19 & 20 & 30 & 18 & 25 & 21.83 \\
\hline & & Illiterate & 81 & 80 & 70 & 82 & 75 & 78.16 \\
\hline \multirow{2}{*}{ X9 } & \multirow{2}{*}{$\begin{array}{l}\text { Female } \\
\text { literacy } \\
\text { (\% pop.) }\end{array}$} & Literate & 10 & 12 & 20 & 15 & 18 & 14.16 \\
\hline & & Illiterate & 90 & 88 & 80 & 85 & 82 & 85.83 \\
\hline \multirow{3}{*}{$\mathrm{x} 10$} & \multirow{3}{*}{$\begin{array}{c}\text { Ration card } \\
\text { type }\end{array}$} & $\begin{array}{c}\text { Yellow } \\
\text { card(APL) }\end{array}$ & 52 & 40 & 36 & 44 & 16 & 40 \\
\hline & & $\begin{array}{c}\text { Red } \\
\operatorname{card(BPL)} \\
\end{array}$ & 32 & 36 & 32 & 32 & 36 & 33.33 \\
\hline & & Without card & 16 & 12 & 32 & 24 & 48 & 24.66 \\
\hline
\end{tabular}

\section{Source- Field Survey, 2012}


UN Millennium Development Goals, India Vision 2020 and QOL in Slums in Varanasi

This section deals with the comparative analysis of the goals and targets of the MDGs and India Vision 2020 while linking it with QOL status of the slum dwellers (please also refer to Table 4). This comparison gives a comprehensive view of low QOL in slums and shows lacunas in policies and programmes.

The UN Millennium declaration had determined certain goals and objectives in the fields of education, health, poverty and environmental sustainability (Kabeer, 2010). These goals and objectives are merely the future which is being imagined or which is essential requisite for good QOL (Bandyopadhyay \& Agrawal, 2013; Ishtiyaq \& Kumar, 2011; Kabeer, 2010; Nath 2011; also Cohen, 2013).

In the field of education, UN-MDG has determined two goals: first, to achieve universal primary education and second, to promote gender equality and empowerment of women. The targets were fixed so that the goals can be achieved in the due course of time. These targets are universalisation of primary education and to eliminate gender disparity in primary and secondary education by 2005 , and in all levels of education no later than 2015. On the other side, India Vision 2020 has the goal to achieve $100 \%$ literacy, school education and vocational training. While in the case of the slums of the study area, about $75 \%$ of the population and $85 \%$ of females are illiterate.

In connection to public health, UN-MDG's first goal is to reduce child mortality rate and improve maternal health also combating HIV/AIDS, malaria and other diseases. The targets to achieve these goals were to reduce under-five mortality to two-third between 1990 and 2015 and achieve universal access to reproductive health and the last target is to control the incidence and decrease it by 2015 . In this context, India Vision 2020 has the goal of expansion of the infrastructure for public health and medical care to ensure health for all. The condition of public health infrastructure in the sample slums is far from reality; the strategies targeted by MDGs and India Vision 2020, failed to reach in Varanasi slums. Less than 35\% household use government hospitals, $17 \%$ consult the traditional practitioners. Besides, the slum dwellers lack safe drinking water supply and only $64 \%$ respondents have HIV awareness.

Poverty is the key cause of poor quality and non-availability of resources. The UN-MDGs have put forward some goals and targets; they are to eradicate extreme poverty and hunger. To achieve this goal, the targets which were fixed are to reduce the population living on less than half a \$ per day and decent employment for women, men and youth population. On the other hand, India Vision 2020 advocates food and nutritional security along with employment for all. While the findings demonstrate that only $34 \%$ of the population have red rationcard to accrue, the benefits of the government sponsored programs while $24 \%$ fails to have any such cards implying no benefits from the government.

In addition, the MDG7 aims at ensuring environmental sustainability. For this, it aims to reduce the loss of environmental resources and to achieve a significant improvement in the lives of at least 100 million slum-dwellers. In familial context, the India Vision 2020 document aims to expand the physical infrastructure; to maximise national prosperity, individual freedom and social equity. However, the real situation of slum dwellers of Varanasi and their quality of lives are rather dismal. Only $24 \%$ of households use the place fixed by the municipality for dumping waste. $64 \%$ residents' uses water from the hand-pump for drinking and $24 \%$ households use kerosene as sources of energy for lighting. Importantly, more than $80 \%$ houses are either kuccha or semi pucca. The Table 7 shows the goals and targets of MDG, India Vision 2020 and status of slums of Varanasi city.

This comparative study of slum dwellers in Varanasi with respect to MDGs and national goals portrays a pathetic picture. In order to achieve these goals, one has to understand the significance of the problems related to slums. 
"In a somewhat more prosaic vein, World Bank president Robert McNamara launched the Bank's shelter assistance programs in 1973, saying, if cities do not begin to deal more constructively with poverty, poverty may begin to deal more destructively with cities"(World
Bank,2006:x). Varanasi is known as a centre of education, religion and culture. It is on the verge of being included in the UNESCO's list of world heritage city. Therefore, it is very essential to alleviate urban poverty and gain overall inclusive development.

\section{Table 4: UN-MDGs, India Vision 2020 and Status of Slums of Varanasi city}

\begin{tabular}{ll} 
UN-MDGs \\
\hline EDUCATION & Goals: \\
& •Achieve universal primary education \\
& •Promote gender equality and \\
& Empower women \\
& Targets: \\
& • Ensure that, by 2015, children \\
& everywhere, boys and girls alike, will \\
& be able to complete a full course of \\
& primary schooling \\
& •Eliminate gender disparity in \\
& primary and secondary education \\
preferably by 2005 and in all levels of \\
education no later than 2015
\end{tabular}

HEALTH Goals:

- Reduce child mortality rates

-Improve maternal health

- Combat HIV/AIDS, malaria, and other diseases

Targets:

-Reduce by two-thirds, between 1990 and 2015, the under-five mortality rate

-Achieve, by 2015 , universal access to reproductive health

- Have halted by 2015 and begun to reverse the incidence of malaria and other major diseases

POVERTY

India Vision 2020

Goals:

-100 per cent literacy \& school education, and vocational training

Targets:

-Male adult literacy rate (\%): 68

(96) percent

- Female adult literacy rate (\%):

44 (94) percent

- Net primary school enrolment ratio: 77.2 (99) percent

- Public expenditure on education as percent of GNP: 3.2 (4.9) percent

\section{Goals:}

- Expansion of the infrastructure for public health and medical care to ensure health for all. Targets:

- Life expectancy at birth in years:64 (69)

-Infant mortality rate per 1000

live births :71(22.5)

- Child malnutrition as \% of children under 5 years based on weight for age:45(8)
Status of Sample Slums

- More than $75 \%$ population is illiterate

- More than $85 \%$ females are illiterate
- Less than 35\% households use Government hospital

- About $17 \%$ household depends on traditional practitioners (jhola chap doctor)

-About $36 \%$ respondents lack awareness about HIV and transitional diseases - $64 \%$ residents of sample slums use water from the hand pump for drinking.
Goals:
- Eradicate extreme poverty and hunger
Targets:
- Halve the proportion of people living on less than $\$ 1$ a day
-Achieve Decent Employment for Women, Men, and Young People
-Achieve, by 2010, universal access to treatment for HIV/AIDS for all those who need it - Halve the proportion of people who suffer from hunger

Goals:

- Food \& nutritional security

-Jobs for all

Targets:

-Poverty as \% of population

below poverty line:26(13)

- Unemployment rate (\% of labour force):7.3(6.8)
-About 34\% households have red card (below poverty line)

-About 24\% households do not have any card; they are unable to receive any govt. subsidies. 


\begin{tabular}{|c|c|c|c|}
\hline ENV.SUST. & $\begin{array}{l}\text { Goals: } \\
\text { - Ensure environmental sustainability } \\
\text { Targets: } \\
\text { • Reverse loss of environmental } \\
\text { resources } \\
\text { - Halve, by } 2015 \text {, the proportion of } \\
\text { the population without sustainable } \\
\text { access to safe drinking water and } \\
\text { basic sanitation. } \\
\text { - By 2020, to have achieved a } \\
\text { significant improvement in the lives } \\
\text { of at least } 100 \text { million slum-dwellers }\end{array}$ & $\begin{array}{l}\text { Goals: } \\
\text { - Continuous expansion of the } \\
\text { physical infrastructure } \\
\text { - To maximise national } \\
\text { prosperity, individual freedom } \\
\text { and social equity } \\
\text { Targets: } \\
\text { Electric power consumption per } \\
\text { capita (kwh):384(2460) } \\
\text { Pucca houses for every slum } \\
\text { dweller (RGHS) }\end{array}$ & $\begin{array}{l}\text { - Only } 24 \% \text { households use } \\
\text { place fixed by municipality } \\
\text { for dumping waste. } \\
\text { - } 64 \% \text { residents of sample } \\
\text { slums use water from the } \\
\text { hand pump for drinking. } \\
\text { - } 24 \% \text { households use } \\
\text { kerosene as a source of } \\
\text { energy for lighting } \\
\text { - Sewage disposal facility is } \\
\text { very poor in sample slums. } \\
\text { - In sample slums more } \\
\text { than } 80 \% \text { houses are kuccha } \\
\text { and semi pucca. }\end{array}$ \\
\hline
\end{tabular}

Source: Compiled from (a) http://www.undp.org.in/ihdg.htm (b) Government of India (2002) \& (c) sample survey (2012)

\section{Conclusion}

The study highlights that low QOL existing in the slums of Varanasi city. The research unfolds that the housing, literacy, sanitation and medical facilities of the slums are very poor. Lack of piped water supply in the slum areas has led the population to depend on ground water. Lack of proper waste disposal facility and poor sewage system has increased pollution and health related problems. All these dismal facilities and the level of disparities are obviously related to the socio-economic setup of the city. The suggestion therefore, is to improve the socio-economic condition, which would improve the QOL of slums. The government has to make serious efforts to upgrade urban slums. In-situ upgradation of slums, wherever possible, with provision of basic facilities need to be taken up. In addition, education can play a vital role for improving the quality of lives in slums. Therefore, efforts must be taken to improve education of the slum dwellers. To achieve the goal of inclusive development, there is a need of inclusive planning for the Varanasi city as a whole. In this process, slums need special attention. Participatory planning strategies for slum upgradation can be helpful to improve the situation. Cities provide better economic opportunities and favourable settings for the resolution of social disparities than rural areas (UNFPA, 2007). However, one should not forget that poverty is growing faster in urban areas than the rural areas. Our future depends on how one deal with unequal development to achieve global as well as national goals and targets. Indeed, the slums of Varanasi and their problems need special attention to achieve the targets of UN Millennium Development Goals and India Vision 2020.

\section{References}

Bandyopadhyay, Abir and Vandana Agrawal (2013).Slums in India: From Past to Present, International Refereed Journal of Engineering and Science, 2(4) pp.55-5.

Census of India (2011). Town Village Directory, available at http://www.censusindia.gov.in/2011census/ce nsusdata2k11.aspx.

Cohen, Michael (2013). The City is Missing in the Millennium Development Goals, Working Paper Series on The Power of Numbers: A Critical Review of MDG Targets for Human Development and Human Rights,An independent research project coordinated by Sakiko Fukuda-Parr at The New School and Alicia Ely Yamin at Harvard School of Public Health ,pp.1-25.

Government of India (2002). Report of the Committee on India Vision 2020. Govt. of India, New Delhi.

City Development Plan (2006). Jawaharlal Nehru National Urban Renewal Mission, Varanasi.

Ishtiyaq, M. and Kumar, Sunil (2011). Typology of Informal Settlements and Distribution of Slums in the NCT, Delhi, Journal of 
Contemporary India Studies: Space and Society, vol. 1. pp.37-46.

Kabeer, Naila (2010).Can the MDGs Provide a Pathway to Social Justice?: The Challenge of Intersecting Inequalities, Institute of Development Studies, University of Sussex, UK.

Nath, Anita (2011). India's Progress Toward Achieving the Millennium Development Goals, Indian Journal of Community Medicine, 36(2), pp. 85-92.

Smith, D.M. (1977). Human Geography: A Welfare Approach, London: Edward Arnold Publishers.

Sundari, S. (2003).Quality Of Life Of Migrant Households In Urban Slums, In Martin J. Bunch, V. Madha Suresh and T. VasanthaKumaran, eds, Proceedings of the Third International Conference on Environment and Health, Chennai, India, 15-17 December, 2003. Organized by Department of Geography, University of Madras, Chennai and Faculty of Environmental Studies, York University, pp. 537-552.

Tripathi, V.K. (2010). Socio-Economic Status of Urban Poor Living in Slums of Varanasi City, Earth Science Review,1(2), pp.47-56

Tripathi, V.K. (2011). Urban Poor Living in Slums of Varanasi city, In Sharma, P. R., Yadava R.S., Sharma, V.N.(eds), Research methodology: Concepts and Studies, R.K. Books, New Delhi, pp. 493-515.

UNFPA (2007). Linking Population, Poverty and Development, available at http://www.unfpa.org/pds/urbanisation

The Millennium Development Goals Report (2006). United Nations Development Programme, United Nation, available at www.undp.org/publications/MDGReport2006.p df

World Bank (2006).Thirty Years of World Bank Shelter Lending: What Have We Learned?, World Bank, Washington DC, USA: World Bank.

\section{About the Authors}

Mr. Darshan Kumar Jha obtained his M.A. (2011) degree from Banaras Hindu University,
Varanasi. Currently he is pursuing his Ph.D. as UGC Junior Research Fellow from Department of Geography, Banaras Hindu University, Varanasi. His research theme is Informal Settlements, Poverty and Urban Planning in Varanasi City. He has also qualified UGC-JRF in Women Studies. He has published two papers in leading Geographical Journals Viz., 'Kosi Flood Hazard and Disaster Management: A Case study of Supaul District' in National Geographical Journal of India and 'Quality of life in Slums of Varanasi City: A Comparative Study' in Transaction, Institute of Indian Geographers. He has also attended and presented papers in various national and international conferences. He has served as Department Representative in University Student Council and also worked as volunteer in area of children welfare and as deputy coordinator for poor weavers support program at local N.G.O.

Dr. V.K. Tripathi is an Associate Professor at the Department of Geography, Banaras Hindu University, Varanasi. He obtained his M.A. (1985) and Ph.D. (1991) degrees from Banaras Hindu University, Varanasi. From 1995 to 2004, he worked in two Government Colleges of Uttar Pradesh viz., Government P.G. College, Ranikhet and Government P.G. College, Mahammadabad, Ghazipur as Lecturer, Senior Lecturer and Reader. He Joined BHU as Lecturer in 2004 and became Senior Lecturer in 2005 and Reader in 2008. His major fields of interests are Urban Geography, Applied Geography and Regional planning. He has published more than two dozen papers on these themes. Currently, he is teaching Urban Geography, Regional Planning, Economic Geography, Geographical thought and an Interdisciplinary course on Urban Studies. He is life member of various professional bodies.

\section{Acknowledgement}

This paper was presented in International Seminar on "Banaras, the Heritage city of India: Culture, Tourism and Development" held at Banaras Hindu University, Varanasi in February 2014. The paper was revised further on the basis of the feedback received from the 
presentation. We would like to thank all the editor of this journal for their valuable participants of the seminar. We also express feedback.

our gratitude to the anonymous reviewers and 